\title{
SKY-Squares and Their Management Organization Structure with Military Physical Education and Miscellaneous Sports Branches in the City Structure of the Seljuk Empire
}

Kepoğlu A*

Usak University, Faculty of Sport Science Turkey

DOI: $10.36348 /$ jaspe.2020.v03i09.002

| Received: 24.07.2020 | Accepted: 02.08.2020 | Published: 30.09 .2020

*Corresponding author: Abdurrahman KEPOĞLU

Abstract

The sky-squares are the institutions that provide both military and socio-cultural services within the structure of the period. In the cities of the Seljuk Empire, the squares gave a regular service in the administration of the officer. In the settlements near the Seljuk fortresses, they also served under the control of the court of residence under the Castle Guard. In the Turkish tribes outside the settlement areas, both military and socio-cultural activities continued in the tradition of decentralized management coming from the Turkic Khaganate and in open and closed upland and winter sports houses. On the other hand, the understanding of power and other states to accept them to make the Seljuk Empire connected to the power of the country as well as seize the trade routes, an important element of the economy seized the trade routes to hold and to organize the commercial activities in a comfortable, easy and safe way, The Seljuk Empire determined its bio-policy on the people of the country as "to be the best fighting society ". To reach the determined bio-policy, it has used all its facilities in an organized way. The Seljuk Empire has achieved this goal thanks to the sky-squares. In addition to military physical education, Sky-squares, which was opened to the use of people living in the city on certain days of the week, contributed both to the activity of the people in various sports branches and to the establishment of the enterprises that produce the sports branch of their interest and to the Seljuk economy.

Keywords: SKY-Squares, Sport Management, Seljuk Empire.

Copyright @ 2020: This is an open-access article distributed under the terms of the Creative Commons Attribution license which permits unrestricted use, distribution, and reproduction in any medium for non-commercial use (NonCommercial, or CC-BY-NC) provided the original author and source are credited.

\section{INTRODUCTION}

In our study, we will examine the Sky-square institution of the Seljuk state. The Kinık tribe, to which Seljuk Beig was liable to, was included in the Turkish unity during the Turkic Khaganate. After the Turkic Khaganate ended, they migrated to the South Caspian region and continued their existence under Oguz Yagbu state. Meanwhile, Kinik tribe, who chose Islam, established their state in 1037. The state lasted one hundred and twenty years. In 1157, the state ended. First Islamic culture and then the civilizations they encountered in migration routes and the cosmological structure they conquered were added to the cosmological structure inherited from the Turkic Khaganate to which they were previously liable. Under all these effects, they had a unique cosmological structure. There are two prominent elements in this structure. The first one is the educational institutions and the second one is Sky-square, which includes military, socio-cultural and sports activities. The conspicuous point in the form of management of both institutions is formal education and decentralized management. The expenditures of both institutions were met from the state treasury.

Our study aims to determine the management and organization chart of the Sky-square, which is a sports venue of the Seljuk Empire. To realize this aim, the meta-analysis method was used. The method is used to reach a synthesis from the results of these studies by examining the researchers conducted for a specific purpose or subject together. Meta-analysis means analyzing the results of a study by combining the results obtained from different studies, as well as re-analyzing the results of a study [1,2].

The following factors influenced the formation of the cosmology of the Seljuk Empire. In the process of migration from Central Asia to Anatolia, which started in the 9th century and lasted for approximately 200 years, with the whole culture of the nomadic and settled life of Turks, as a result of their contacts with a 
number of different nations and cultures; as a product of the mutual interaction of the Persian-Islamic and Indian culture spread in the Khorasan, Transoxiana and Persian-Iraq regions and the Roman-Greek cultures and civilizations in Anatolia, the cultures of Central Asian city life are not seen in the Islamic world in Anatolia and non-conservative Turkish-Islamic culture and civilization [3].

One of the most important elements to be considered about the sport was the establishment and operation of sports lodges while Seljuks were urbanizing. Even, it is known that Nizam al-Mulk, vizier of Sultan Malik-Shah I, was working on this issue intensively [4]. In this way, the sport was organized by the state to organize the sports, as well as sportsman training, protection, and nutrition. The sport was also influenced by the changing urbanization culture. In particular, it played an active role in ensuring security and urbanization in rural areas. The most striking example of this was the establishment of sports lodges for various branches in rural areas where urbanization was possible. As urbanization began, these sports lodges and buildings belonged to those lodges became a district of the city.

When the Seljuk culture and civilization are studied artistically within the context of the historicalspatial boundaries and the differences between the Islam-Christian or Iranian-Turkish or Central AsianTurkish cultures, nomadic-settled differences and historical-spatial boundaries; The group from Tokat, Niksar, Sivas, and Kayseri, where the group from Khorasan and Central Asia was heavily settled, had the traces of the ancient shamanic philosophy of the Middle East traditions of Danishmend province; In the influence of Iranian culture relations on the basis of the intensity of the relations between the former and the Malatya-Harput areas, the Central Anatolian region, which includes the capital Konya and its environs as a political center, suggests that it has a unique and artistic understanding of the synthesis of Christian-Islamic cultures. More generally, it can be said that the culture and civilization of the Seljuk culture organized in the Anatolian geography unites with the Iranian culture and the Central Asian Turkish traditions in the lifestyle dimension, and that it is fused with Christianity in the religious dimension and that it is based on the religion of Islam although it carries the traces of the old Shaman past [3]. The names of the settlements established in the newly established settlements or the names of the settlements where the Christian population is the dominant element under the Turkish folk etymology, and the traces of the Turkish place names in the Central Asian and Iranian Turkish geography, reveal that the nomadic and settled Turkish cultural heritage has been moved to Anatolia. It is known that the tradition of giving titles to some important and big Anatolian cities in the period of the Seljuk Empire is the legacy of IranIslamic urban culture and civilization and culture moved to Anatolia [5]. As a result of these developments, it is seen as an inevitable result that Central Asian and Iran-Islamic cultures and civilizations have an effect on the spatial organizations which constitute the system of Anatolian Seljuk cities and their influence on topology (Science dealing with place name) origins [3].

To understand the sports culture in the Seljuks, it has been tried to be determined according to the resources we can reach. The mobility in the sports and entertainment life of the Seljuks draws attention. It can be said that the social life mobility in the Seljuks is reflected in the sports and entertainment culture in the light of some details between the sources reached until today and some details in the events. The sport, which is an important element of culture, is also a continuation of the previous Turkish states and it can be said that the Oghuz ceremony was transferred to Anatolia almost without decomposition. The sports are usually training for the preparation of the war. However, these sports branches were adopted by the people in time and when there was no war, the rules were adopted or applied by changing the rules. The Seljuk sultans tried to improve themselves in the field of sports like every individual. The fact that the training materials of the Seljuk sultans reached so far explain this situation. Remarkable sport is such as wrestling, archery, ambling, equestrian, and hunting. In the related sporting activities, the struggle against nature and one-to-one struggle are observed without harming the other. As mentioned before, although the sport was regarded as the nature of the war, it has affected every point of life. There are frequent sports competitions in wedding ceremonies, festivals and boarding ceremonies. Those who were successful in sports competitions would both rise to a reputable position and be rewarded. Colorfulness in sports life is also reflected in the entertainment life. In particular, It is often mentioned in entertainments and feasts in Ibn Bibi's work. These feasts are usually held in large spaces where public sultans can be intertwined. Also in women and feasts; they shared the same position with the men in the sporting events organized in the feasts. Then all these cultural elements intact and passed to the Ottoman Beylik and most have reached today. It is possible to explain the epistemological and conceptual meanings of the sky-squares holding an important place in the Seljuk city structure as follows.

\section{Conceptual Dimension of Sky-square}

The sky-squares existed in almost all of the Turkish states established before and after Christ. Especially in the Seljuk Empire and later in the Turkish states, Sky-square continued to exist as an organization even though its management changed. This situation has maintained its validity during the states of the Anatolian Seljuk, Ottoman, and the Republic of Turkey.

In the Turkish thought system, it was accepted that the ruler's right to govern was given by Tengri, and 
the qualities that the rulers had or should have were called "blessing". The sovereign power, which has a temporary, daily and seasonal character, has been accepted as the power and sovereignty of the state administration, the power of domination, the extension of the state and the God in life, happiness, value, and auspiciousness. The understanding of "Blessing" has also made the sky blessed since God was thought to be in the sky. This has led to the development of various rituals and beliefs. In this context, the name "Tengri" has been accepted as an expression of power, and eternity in the sense of the divine Turk belonging to the sky. This principle of thought has given rise to the use of the word heaven as God in the Orkhon Inscriptions and in this context, the name Göktürk was accepted as the reflection of the holiness of the sky to a nation [6]. That the founders of the Seljuk Empire changed their religion and converted to Islam, the change in social life, differentiation of conditions and the restructuring of values over time led to the changes in the structure of "Blessing" belief which was believed to exist in heads of state. With this change in political governance, the sacredness brought by the blessing and the blessing is synthesized by the cult of ancestors and finds a living space at a different point. This new area somehow finds itself in every area of the sacred signs [6].

The concept of Sky Square has found its place in the cosmology of the Seljuk Empire in the sense of the place where the expression of power, force and eternity in the sense of heaven belongs to the sky. On the other hand, the epistemological uniqueness of the concept of the square has expanded according to the cosmological development process of human beings. These changes and developments occurred as shown below. According to Akdoğan [7]; Square is expressed as open spaces where the public is gathered for social, religious and commercial purposes, and which are the scene of military and political demonstrations. According to another definition, the square is a wideopen area that serves as a meeting place for urban people by initiating and directing urban circulation and these areas are the focal points or focal points of all kinds of settlements [8]. Another definition of the word square is that it is a limited space surrounded by a natural environment and/or built environment elements. The challenge also allows for individual activities depending on individual activities, whether in the city or the village. It is available for individual and collective events without any payment. Structures surrounding this public land occur in time during the historical development process [9]. The squares can also be referred to as urban life with the name of a particular function, a special activity, a special structure or any object in it [10]. The squares that served an important purpose as a social and cultural meeting point were also found in the Central Asian Turkish cities, which constitute the historical basis of the Seljuk city culture. There are various squares in Samarkand and Bukhara. The center of Khorezm in the Khorasan side was a square similar to Bukhara Square in Cürcâniyye, where sheep were sold. Tirmiz, the largest city on Ceyhun, had large squares [11]. Concerning this information given about the historical continuity, it will be appropriate to contact the Seljuk cities in Iran geography. Before the Seljuks, it is known that there are squares in Iranian cities in the center of the city, where the important streets meet and the market is opened. In the center of the city, there were palaces, divans and a mosque. The city is the most beautiful example of this. When Abbasid caliph Harun al-Rashid came to Nisaphur, he lived in a mansion in Telâcird square. When the Seljuk Sultan Tughril ruled Nisaphur, he lived with the state head of the palace in the square, which was the administrative center of the Ghazni sultans, stated as Shadyah (Shaziyah or Dârüazl-Emân) or as Shadyah Square [12]. During the Seljuk period, archery, horse riding, javelin, and ambling were performed in the squares which became a part of civil and military life. At the time of the Seljuk Empire, the horse was ridden slowly at a certain distance every day; the rider and horse were trained here with various methods of warfare. The word "square" was used as a scale in this period [13]. Chovgan was the most played game in squares. Malik-Shah I used to play chovgan, as well. The square, which is used as a training and exercise area during the Seljuk period, is depicted as a green and grassy field that covers a wide area outside the city walls. Because of this feature, squares in some places is also called the sky-square [14]. The area surrounded by a square should be almost the size of all people living in the city. Ibn Bibi stat that in the battle of Yassi Chemen, Seljuk and Harezm armies encountered in the order, the distance between the two is not as much as the two squares are described in the poem [15]. The width and length of a normal square were calculated as 1000 cubit [16]. In this case, the square is around 4000 cubit, and the inner area is $1,000,000$ cubit square [17]. The current value of this measure is $\mathbf{5 7 4 . 1 7 0}$ square meters. It is thought that the existing squares in the twenty-six Seljuk cities are about the same size. As it is understood, the square, which was also a common activity area, was extremely wide [12].

The cities, which were acquired in the time of the Seljuk Empire, were transformed within the framework of their cosmology. Army and economy, which are two important elements in the continuity of the state, were reorganized together with urbanization. This arrangement has allowed institutionalization of the sky-squares. Horse and horse breeding, which are the most important elements of the army and economy, have been developed in Sky-squares. Ergonomics have been tried to be achieved in horse breeding, which is the input of both the army and the national economy. The cavalry training that can utilize the war vehicles expertly on the horse was made in the squares established near the gates of the cities. 


\section{Perception of Body and Sport in the Seljuk Empire}

When we examine the primitive understanding of the elements affecting the body and sports perception of Seljuks, the cosmological heir of Göktürks. The individuals who make up the Göktürks have learned the active and passive membership roles of their countries through their political socialization, internalizing the system of ideology and values, and gaining social status in the Göktürks with the bravery institution, even if they do not come from the Asina lineage, they are placed within the social system [18]. Under the influence of Islam in the Seljuk Empire, bravery institutions continued with some changes. Biopolitics is part of realizing the control and regulation of bodies on a population scale. In other words, Individuals brought together at certain periods within the production site are also aimed to be separated from each other individually and distributed to the place. This is the framing method of the discipline. "Every individual has his place, an individual everywhere. Avoiding distribution in groups; jointly settle settlements; to analyze complex, mass or elimination plurals. The disciplinary space is directed to allocate as many parcels as the body or element to be subjected to distribution [19]. The Seljuk Empire was making the population productive by subjecting their bodies to formal education in madrasahs, and military training in Sky-square. On the other hand, it was controlling over the people through cultural activities, various sports activities, reward and punishments in this square, giving control over the bodies.

\section{Purposes of the practice of Sky-squares}

The first information about the use of the squares was reached at the time of the Göktürks and continued with the Seljuk Empire. In the cosmology of the Seljuk Empire period, the sky squares provided the four basic elements which were; economy, military physical education, socialization, and sport. One of the most important elements to be considered about the sport was the establishment and operation of Skysquare institutions while Seljuks were urbanizing.

The economic approach of the Seljuk Empire had three objectives following the archaic period. The first is to plunder and take tribute by raiding towns and cities. The second is to seize new territories to provide food to the army. Both of these goals are economic. The Seljuk Empire must produce economic surplus externally. This organization, which has exterminated externally, caused the formation of a second power competition organization based on physical force among Seljuks for the state, emirate, height or conquests (smaller nomadic settlements) which were located around it. The result of both organizations is to be the best fighting community [20]. The third one is the protection of the trade routes and ease of use for the beneficiaries. If this situation was successfully organized in Seljuk cities and settlements around the Seljuk fortresses, the state could ensure its continuity. For this reason, both horses and soldiers were subjected to combat physical education. For the state to be successful, trained soldiers and horses were needed. For this reason, the findings of the researches about the field show the aim of using multidimensional use of the sky squares. Findings related to this subject are as follows. During the Seljuks, the squares had an important position as the places where the managers and the public were allowed to live individual or social freedoms outside daily life [12]. Horse and horse breeding have an important place in Turkish culture. The historians working on this subject agree on the fact that the horse was first domesticated and used in military, economic and living areas by the Turks. Under the light of this information, we can say that one of the reasons for the conceptualization of the squares by Turks is the horse breeding for economy and military. The reasons why we came to this conclusion can be listed as follows. Four-legged animals perform their movements with a combination of various leg movements. Ambling may be congenital in some horses, but can also be taught later. The racking technique is generally based on the method of moving forward and rear legs on any side of the horse at the same time and pressing the ground simultaneously. Ambling horse has high efficiency. In other words, it can carry more load in less time, less distance to long distance. The first written data about the concept of ambling (Yorga) is mentioned in the sentence of Uighur stele in the 8th Century as "I speared his army in yorga race." Here ambling is given as a stepping name. Another inscription, the Tonyukuk inscription, set in 725 , states that one hundred thousand soldiers were gathered in the race plain and the plains mentioned took their names from the horse races held for various reasons. The name of the place in the inscription of Uighur stele in the sense of "ambling", it also depicts the existence of a sporting field designated for ambling horse at the beginning of the eighth century. The Turkish horse and horseback was brought from Central Asia to the Middle and the Near East by the Seljuks and was further developed [21]. The other reason is that the Turks have shown much better performance in their archery (Tirendaz), which is another kind of war games. There are two reasons for the archers' achievements in this sport. First, they are Turkish bowmen. A Turkish bow needs five to six years to produce. The second one should be sought in the deeply thought-out and systematic training of Turkish archers. This Turkish sport has every condition of a modern sport [22]. To be the best warrior society, the Seljuks, who have settled to life, have created and organized sky-squares. As they reach these goals, many sports branches have been applied regularly through their contributions. The use way of Sky-square by the Seljuk Empire government's is surprisingly similar to the principles of scientific management that Taylor proposed in 1905. That is, with the training of people and horses in the Skysquare, Taylor 'We are all looking for qualified personnel who are trained by others. However, the only way to proceed with the steps towards national 
productivity is to realize the necessity of creating systematic cooperation that will reveal and develop qualified people instead of hunting people who are trained by others. The first objective of any system should be to train people in first class. The person who is capable of systematic management will reach the summit much faster and more precisely than the previous systems. The Seljuk Empire government acted following Taylor's "maximum prosperity, but with maximum efficiency. This logic is following "The most important feature of both the employees and the management is to be developed and educated so that people can reach a fast and the most productive level to the extent of their abilities." In light of this logic, we learn from Ibn Bibi that the power of the Seljuk Empire was planned and organized for both war and economic purposes. Likewise, Taylor's labor productivity efficiency is a description of the rule that the limits of a person's capacity are limited to the types of work he has reached because of fatigue. This is the rule of a heavy work that resembles the work of a horse cart rather than a running horse. In practice, this kind of work requires the man to push and pull heavily with his arms; In other words, it is the power to do something by pushing and lifting something that they hold in their hands. In this case, the rule is that every time a push or pull is made for the arms of the worker, the worker may only be working in certain parts of the day. For example, in the transportation of pig iron, each of which weighs 92 pounds, while a first-class worker can only work in $43 \%$ of the day, he is supposed not to work in $57 \%$ of his time. Therefore, if a worker carries half a peak weighing 46 pounds, he will carry a load of $58 \%$ of the day and remain empty in $42 \%$ of the day. As the burden rises, the worker will spend more days working, and this will continue to the point where the worker can carry his load with his hands all day without getting tired Taylor, 2016. The rules of the chovgan sport (now called polo), which was performed in sky-square, were first created by the Turks [23]. For the Seljuk Empire power, the importance of this sport is that it is a freetime activity for military training and public. From the relevant sources, we know that the Seljuk Empire established and operated the first formal education institutions within the understanding of decentralized management. There are two logic systems put forward by Robert Owen. First, "The character of the person is not created by himself, but the environment." Second, "By applying certain methods and tools, any character can be given to each community, increasingly to the world, from the worst to the best, from the most ignorant to the most intellectual. These methods and instruments are also largely under the control of the sovereigns of the nations". Owen believed that the ideal society could only be established as a result of good education for children and young people. According to him, children should be educated starting from a young age [24]. This sport which was practiced and taught by the Turks in a very early period, especially as military training in equestrianism, is a game not only for men but also for women and girls. The people were so impressed by this game that they were playing at night even by lighting. 10-foot-long candles were used for lighting. There was a great luxury at that time. The balls were being saved in gold boxes and decorated with red leather. The chovgans were made of coated wood and they were dressed up [25]. For these reasons, sky-square was also used in public education.

\section{In the Seljuk Cities}

During the period of the Seljuk State, the Turks abandoned the nomadic settlement concept and started urbanization. This has brought about a positive and negative impact on the social layer of society. Some Turkish tribes did not leave nomadic order and even opposed the central will from time to time. However, the urbanization process continued. The unchanging element is that there is no difference between civilians and soldiers in the Seljuk State.The society converted to Islam has maintained its characteristic since Central Asia. This feature influenced the city structure of the Seljuks. It is one of the reasons for the organization of Sky-square.

Urban spaces started to emerge with the city. Together with the geography and topography conditions in which the cities were established, the lifestyles of the city founders have diversified and developed the places in the city. The spaces other than the residential areas defined as housing constitute the common usage areas of the city. Since the emergence of public perception, these areas are called public spaces. Since the emergence of public perception, these areas are called public spaces. In the Islamic civilization, which foresees a perception of life that cares about human movement, the city is positioned in such a way and that shaped the spaces accordingly [26].

When both urban and non-western urban developments are considered, it will be seen that three important factors are trade, military purposes and the phenomenon of religion. These three types of organizations have brought out the cities, and the changes that have occurred over time have been reflected in the urban space and led to changes. Although it cannot be determined exactly which religious and military factors were effective before, it can be said that commercial space organization came after the two. However, nowadays, space has been separated from the place, society, and the individual who make up the place and has become open to distant social influences. Under the influence of globalism, the interaction of everyone-everyone, everyone-everything, and everything-everything have ceased to be original and monochrome urban spaces have begun to emerge. Jacques Ellul describes this situation as "global unity" [27]. If we define this situation through space, it may be appropriate to use the concepts of spatial unity or spatial similarity. One of the noteworthy issues in the 
asset evaluation of urban space is that the state and the city are in a must-have relationship. According to Ibn Khaldun, being a state necessitates living in the city [28]. The reason for this is the fact that people can survive as a social being and that the state can defend itself only in the city. According to Ibn Khaldun, cities are also indicative of the power and splendor of the state [28].

During the Seljuk period, archery, horse riding, javelin, and ambling were performed in the squares which became a part of civil and military life. At the time of the Great Seljuks, Horse was ridden slowly at a certain distance every day; the rider and horse were trained here with various methods of warfare. The word square was used as a scale in this period. Chovgan was the most played game in squares. Malik-Shah I used to play chovgan, as well. The culture and tradition seen in the Seljuks Empire were kept alive by the Turks in Anatolia [12].

According to the information given by the sources, it is known that Kaykhusraw I and all the sultans who came after him played chovgan. Because it is a game that is played frequently, it is seen that the chovgan bar is depicted quite a lot among the various motifs [29].

A result of city-based life is entertainment and exercise. As the cities were very cramped, a suitable lawn on the edge of the city, adjacent to it and opening a gate of the fortification, was directly allocated for this purpose. These places, which are called Sky-square, can be considered as the most important social institutions of the cities since they are always covered with lush green grass. In this area, the people could perform eid prayers and almost all the people of the city could come together. Festivities after the feast were also performed here. All kinds of shows that interest the city and local people closely were held here. In throne center cities like Konya, ceremonies and festivals of the throne were performed here. In other cities, all kinds of festivities (navy) were held here. In the meantime, the punishments that society should see were executed here. The sky-squares were also places for training. Here horse running, wrestling, archery were practiced, in short, almost all the exercises could be performed. Skysquares are the most important social institutions of the Seljuk era, rather between the 12th and 15th centuries with their versatile features.

In the Seljuk period, shooting archery was one of the most important social activities that have become a part of daily life such as entertainment and sports. In the Seljuk city squares, the whole community including sultans used to shoot arrows, ride horses and play various games such as javelin and chovgan. Just like the sultans, the elders of the state used squares for many social activities $[15,30]$. Sahib Shamseddin Muhammad, the Seljuk reign leader, usually came to the square after the afternoon prayer, where he shot arrows, rode horses, played various games and played sports. The pumpkin game, which belonged to Turks, was a shooting game. In Mosul tribe, the game of pumpkin was performed by archers. Archers would aim at the wooden circle on top of a pole erected on the ground. It was named after an archer on a horse shooting at a golden or silver gourd-shaped target at the top of the pole. The post where the pumpkin was hung to 5-meter high. Sultans and principals also played this game. It is known that Nûreddîn Mahmud Zengî played this game. Bow and arrow making was an important profession because it was an important war and sports equipment of the era in Sultanate of Rum. The Turks used to make bows and arrows in their own countries. The arrow-making master was called an archer, and a bow-maker was called a spreader. Similar expansions were used during Ilkhanate. Also in this period, arrowhead masters were called as tirkeş-duz [31-34]. The arrow-making masters practiced in the bazaars in the center of the Anatolian Turkish city. The place where only the arrow masters work together is called the "Archers Market" [35]. Another element reached from these explanations is the presence of enterprises that made arrows, chovgan and spears during the Seljuk period. The products produced by these enterprises are used in both the military and sports sectors. One finding that will strengthen this assessment is the establishment and operation of family companies during the Seljuk period. These companies are of two kinds. The first was Joint Stock Companies. Many people who put capital at different rates would come together, and this would be left to one or more people. Profit or loss resulting from the activity was shared. The second type of partnership is called a half partnership [36]. Later, family partnerships were established. Examples of such partnerships were also seen during the Seljuk period. By establishing multi-partner companies, the companies paid profits or interest to their partners. During the period of Mongol rule, some Mongolian khans, Hatuns, and Noyans became partners in this company and received profit and interest [17].

\section{Castles and Settlements Nearby in Seljuk}

As a result of the settlement policy of the Seljuk Sultans, various Turkish tribes had the opportunity to settle in many parts of Anatolia. Cities such as Sivas, Tokat, Amasya, Antakya, Isparta, Burdur, Muğla, Gaziantep, Kahramanmaraş, Yozgat, Tarsus, Trabzon, Bayburt, Gümüşhane, Giresun, Ordu, Samsun, Malatya, Erzincan, Tunceli appear to be important settlements. Turkmens who conquered Anatolia settled in their conquests following Turkish state tradition. Abu'l-Fida, after determining the geographical boundaries of Anatolia, stated that the Turks lived here [37]. After the Battle of Malazgirt in 1071, a migration channel between Anatolia and Turkestan occurred. For nearly two hundred years, the majority of Oghuz Turks migrated to Anatolia through this channel. Again, some other Turks were coming to 
this country, not as many as the Oghuz Turks. In other words, this migration movement took place for a long time. During this long period of immigration, the Turks brought their tents, their animals, their nomadic and settled cultures, their weapons, their clothes, their literary values, and their culture as nomadic, seminomadic and inhabitants. The Turks who came to Anatolia also had a Muslim identity. Thus, they will be able to integrate both the traditions and cultures of Central Asia as well as the institutions they took from Islamic civilization [38]. Therefore, the horse is the only and important means of transportation during the archaic period reveals the fact that the presence of a noose for the training of the horse later gave special importance to the equestrian sport of Göktürk society. As a result of today's research, it has been observed that throwing back arrows on horses is the result of very long regular and organized physical training and experiences. In the acquisition of this skill, the background of an institutional structure with central and provincial organizations is seen [18]. After the Turkic
Khaganate came to an end, the subordinates of the Kyrgyz and Uighurs continued their existence in terms of the provincial organization. This situation continued in the Seljuk Empire. The tribes living close to the city trained their horses and soldiers in the sky squares under the supervision of the castle guard. On the other hand, children living in rural areas continued their activities in summer-winter outdoor-indoor sports houses.

\section{Management and Organization of Sky-squares}

Education and social life in the Seljuk Empire were governed by a decentralized administration under the umbrella of the state. The education was formalized and financed by the state itself with the establishment of Nezamiyeh. The social life of the society has been gathered around the sky square, providing both military and cultural and economic continuity and unity. The management and organization of Sky square, which exhibits a decentralized structure, is analyzed as follows in the light of the obtained information.

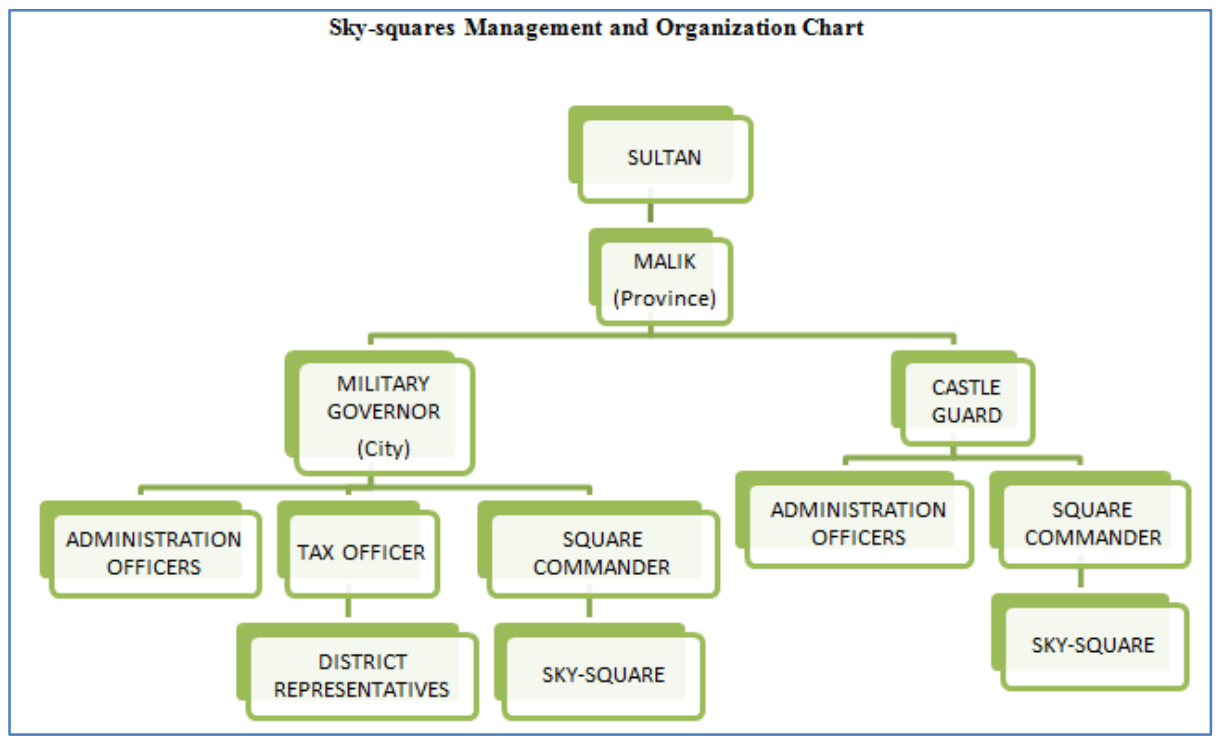

In Seljuks, public order and internal security were carried out together with foreign defense. The various institutions involved in the defense of the country have played an important role in ensuring peace and security in peace. The Seljuks were influenced by some institutions of the Muslim-Turkish states, the Sassanids, the Samanis, the Byzantines, the Umayyads, and the Abbasids, which were established before him and they have replaced these institutions in their structure. There were no police, gendarmerie and private security institutions in Seljuks that would provide public order and internal security like today. They ensured public order and internal security through military units and by groups with important roles in society. The Soubashi, who had important duties in the Seljuks, served as army commanders in times of war, and in peacetime, they both prepared their soldiers for war and fought against the people who disrupted the public order in their regions. While many of the institutions in the field of military duties provide public order, they also take on the role of preventive services and struggle for the protection of the existing structure. The institutions that had military duties in Seljuks performed their internal defense duties while performing their foreign defense duties [39].

In Seljuks, public order and internal security were carried out together with foreign defense. The various institutions involved in the defense of the country have played an important role in ensuring peace and security in peace. The Seljuks were influenced by some institutions of Muslim-Turkish states, Sassanids, Samanis, Byzantines, Umayyads, and Abbasids that had been established before him while performing the public order. There are no police, gendarmerie and private security institutions in Seljuks that would 
provide public order and internal security. They ensured public order and internal security through military units and by groups with important roles in society. Soubashi, who had important duties in the Seljuks, served as army commanders in times of war, and in peacetime, they both prepared their soldiers for war and fought with the people who disrupted the public order in their regions. While many of the institutions in the field of military duties provide public order, they also take on the role of preventive services and struggle for the protection of the existing structure. The institutions that had military duties in Seljuks performed their internal defense duties while performing their foreign defense duties [39].

On the other hand, the rearing and training of horses, an important element of both the economic and the war apparatus, was important in the archaic period. The Seljuks also used it in the training of war horses in the Sky-squares The Turkmens bridle the head of the foal at the age of one year and carry them in tow until they are used to. In the second stage, they fill two small sacks of hay or fresh grass and hang them on both sides of the foal and carry them for a few days. In the third stage, they put a small child on the sack. In the fourth stage, they probably put a child on the saddle instead of the sack. By the age of two, the foal has learned everything. It is stated by Mübârek Zengî that the foal raised in this way does not acquire any bad temper. This type of education continues until the age of five. Then the second stage in horse training begins: Turks taste horses running around a length of "square" each day. In the meantime, as they run the horse from the right one day and the left the other day, they rotate the horse once with the right hand and once with the left hand. Thus, the horse is accustomed to turning easily around. The third stage in horse training starts with the teaching of chovgan and spear play. The initial consideration is to move slowly and effortlessly. In the meantime, while the tired horse rested, training with another horse continued. When starting the training with the rested horse, it is considered to run as much as in the first training. The point that is considered in the game chovgan is that the horse is not scared of the ball at the same time and that the ball does not hit the face and eye of the horse. It is harmful if the ball hits the horse. If the horse appears to be scared of the spear during the training, it is run slightly without spears for several times, then several times a half trot and several times a full trot is performed. So the horse that runs without a spear for a few days is run with a spear until it learns [40].

As stated in various sources, Sky-squares were located close to the gates of cities and were ruled by the square commander. In terms of use, there was no difference between civilians and soldiers in the Seljuk State like the Turkish states before. For this reason, the Sky-squares were mostly used for military training. Besides, on certain days of the week, the people from the city were also involved in sports and other recreational activities within a certain order under the direction of the square commander.

The administrative and organizational structure of the Sky-square in the Seljuk Empire emphasizes the importance of the management function in the periods proposed by Fayol in 1917 and the classical functions such as procurement, sale, and finance are given importance in the institutions and includes the management function into the functions of classical institutions. In his opinion, the basic functions of the institution are grouped into six groups. Technical functions (production, manufacturing and transformation), commercial functions (purchase, sale, exchange), financial functions (principal procurement and administration), security functions (protection of goods and persons), accounting functions (inventory, balance sheet, statistics) and management functions (foresight, organization, command, coordination and control) are common functions that can be seen in all types of institutions [41]. Regardless of the size and type of institutions, the management function has an important role in the functioning of the institutions [41]. Fayol repeats the known form of the material order formula related to the understanding of the organization and sets out the social order formula similar to this formula. According to the formula of the material order, there is "a place for everything and everything is in its place" while the social order formula says "a place for everyone and everyone should be in their place" [41]. In this respect, the Sky-square institution is organized in terms of space and operation similar to the material order formula following this conclusion of Fayol. Particularly, a specific place in the city has been reserved and its bounds have been deliberately determined with various features for Sky-squares following the activities to be carried out. These characteristics are arranged for physical training for horse breeding and military training, and periods for sports and leisure activities of the people in the city. On the other hand, in Fayol's management thought, the material and human elements of the organization constitute a double component of the organization definition. Positioning the production elements within the institutions and organizations according to the quality of the products (training of warhorse and warriors, horses to serve for commercial purposes, sports activities in various branches that socialize the city people) and services produced in Sky-square is an activity undertaken within the scope of the organization. In the administration and organization chart of the Seljuk Empire, the Sky-square institution with the decentralized understanding has taken its place under the governorship of the city governors. In the same way, the provision of qualified personnel who will ensure the functioning of the institution and the organization by using material means and the employment of the appropriate units within the organization is another function of the organization activity. From this perspective, horse breeders, 
groomers, soldiers, square personnel were assigned under the title of Square commander and the human element of the organization was combined with the material element in the most appropriate way. Besides, it is understood from the written sources that the women in the city plays a role in the solution of the problems for Sky-square. This situation offers us the completion of the structuring in legal terms. The Seljuk Empire made the material and social tools in Skysquares two complementary parts. In this way, both of them are organized optimally and have made the operation and success of the sky squares positively effective. According to Peaucelle, Fayol probably represents the first one in 1888 because of his organizational chart drawing and job descriptions. Likewise, it is necessary to see Fayol's document communication among organizations as an innovative application [42]. When we look at the decentralized structure of Sky-square, we can exchange documents between the units through the civil servants in the organization.

According to Fayol, organizational charts make it possible to see everything at a glance, up to the details of an institution, and facilitate the formation and monitoring of the social structure of the institution. Although it is possible to see the hierarchical structure of the organization completely in the organization charts, the personal values, duties, and responsibilities of the employees should not be sought. There should be specific explanations to be added to the organization charts for such information [41]. The management and organization chart of the Sky-square Corporation is based on the data obtained from Fayol's perspective. The details of the organization chart created cannot be clearly stated. With the new findings of the new studies to be conducted in this field, the personal values, duties, and limits of the responsibilities of Sky-square employees can be determined more clearly.

\section{CONCLUSIONS}

In the Seljuk Empire, the sky squares and sports lodges stand out as effective sports organizations. The sky-squares are the institutions that provide both military and socio-cultural services within the structure of the period. In the cities of the Seljuk Empire, the squares gave a regular service in the administration of the officer. In the settlements near the Seljuk fortresses, they also served under the control of the court of residence under the Castle Guard. In the Turkish tribes located outside the settlements, both military and sociocultural activities continued in the open and closed spring and winter sports houses with a tradition coming from the Göktürks. Sports and physical activities have made important contributions to the dynamism of the general economy in every period. Besides, the government has reached its goal using the sky squares, which use all facilities to become the best fighting society. In addition to military physical education (both man and horse during the period), Sky-square, which was opened to the public on certain days of the week, caused the public to operate in various sports branches as well as the establishment of the enterprises that produce the sports branches of the sports branch and their contribution to the Seljuk economy.

\section{REFERENCES}

1. Büyüköztürk, Ş., Kılıç-Çakmak, E., Akgün, Ö., Karadeniz, Ş., \& Demirel, F. (2008). Bilimsel araştırma yöntemleri.

2. Neuman, W.L. (2007). Toplumsal araştırma yöntemleri-nitel ve nicel yaklaşımlar. (Çev. S. Özge), İstanbul: Toplumbilim Dizisi.

3. Özcan, K. (2006). Anadolu da Selçuklu kentler sistemi ve mekânsal kademelenme.

4. İşcan, F. (1988). Türklerde spor. Ankara: Milli Eğitim Basımevi; 1988.

5. Artuk, I., \& Artuk, C. (2003). Bazi Islâm Şehirlerinde hangi devletler sikke kesmiŞ ve bu Şehirlere ne gibi isimler verilmiŞ. Belleten-Türk Tarih Kurumu, 67(249).

6. Öncül, K. (2010). Kültürel sürerlilik ve kut taşıyıcılığı. International Periodical for the Languases, Literatureand History of TurkishorTurkic, 5(2):

7. Akdoğan, G. (1962). İstanbul peyzajının tanziminde peyzaj mimarisi ile ilgili problemler ve ana prensipleri. Ankara: AÜ. Basımevi.

8. Küçükerbaş, E. V., \& Özkan, B. (1994). Bir Meydan Tasarım Sürecinin Germencik Örneğinde Ortaya Konulması. EÜ Ziraat Fak. Peyzaj Mimarlığ Bölümü, Bornova, İzmir, 36 s.

9. Suher, H. (1998). Kent planlama sürecinde kent meydanlarının yeri ve işlevi. Peyzaj Mimarlı̆̆ Dergisi, 4: 5-6 (In Turkish).

10. Zucker, P. (1959). Townand square from agora to the village green. New York: Colombia University Press.

11. Şeşen, R. (2001). İslâm coğrafyacılarına göre Türkler ve Türk Ülkeleri. Ankara: TTK.

12. Metin, T. (2013). Türkiye Selçuklu Şehirlerinde" Meydan Kültürü". Tarih Incelemeleri Dergisi, 28(1), 209-222.

13. Köymen, M. A. (1992). Türkiye Selçuklu Devletinde Ekonomik Hayat. Türk Dünyası Tarih Dergisi, 65, 16-27.

14. Baykara, T. (1985). Türkiye Selçukluları Devrinde Konya (Vol. 44). Kültür ve Turizm Bakanlığı.

15. Öztürk, M. (1996). İbn Bîbî, El-Evâmirü'l-Alâiyye Fî'l-Umûri'l-Alâiyye. Türkçe Tercüme: Mürsel Öztürk, Ankara.

16. Uğurlu, M. (1987). Mûnyetû'l-Gûzât(Haz. Mustafa Ŭ̆urlu), Ankara: T.C. Kültür ve Turizm Bakanlığı Yayınları.

17. Köymen, M.A. (1992). Büyük Selçuklu Imparatorluğu tarihi. Ankara.

18. Kepoğlu, A. (2018). Göktürk Devletinde Spor Yönetimi ve Organizasyonu.

19. Foucault, M. (2019). Hapishanenin doğuşu, (Çev. MA. Kılıçbay), İstanbul: İmge Kitabevi. 
20. Divitcioğlu, S. (2015). Oğuzdan, Selçukluya. İstanbul: Alfa Basım Yayım Dağıtım San. Ve Tic. Ltd. Şti.

21. Yıldıran İ. (1999). Kavramsal ve fonksiyonel açıdan türklerde yorga/rahvan biniciliğin tarihsel gelişimi ve Türkiye'de geliştirme perspektifleri. Gazi Beden Ĕgitimi ve Spor Bilimleri Dergisi, 4(2): 43-58.

22. Ritter, H. (2010). Ata binmek, ok atmak. Türkiyat Mecmuası, 4(10): 45-48.

23. Güven, Ö. (1992). Spor anlayışımız ve sporun sosyo-psikolojik işlevi. G.E.F. Dergisi, 8(1):40-48.

24. Aybay, R., \& Eroğul, C. (2005). Sosyalizmin öncülerinden: Robert Owen: yaşami, eylemi, ögretisi. Yapı Kredi.

25. Kinzler, İ. (1947). Die Leibesübungen der Zentralasiatischen Völker. Inauguraldissertation Zur Erlangung des Doktorgrodes, Grazim November.

26. TAŞÇI, H. (2012). İslâm ve Batı Şehrinde Kentsel Mekânın Kimlik Bileşenleri. Kent Akademisi, 5(10), 52-70.

27. Ellul, J. (2003). Tekonoloji toplumu. (Çev. M. Ceylan), İstanbul: Bakış Yayınevi.

28. Urgan, Z.K. (1997). İbn Haldun, Mukaddime. (Çev. Zakir Kadirî Urgan), Milli Eğitim Bakanlığ1 Şark İslam Klasikleri. İstanbul: Milli Eğitim Basımevi.

29. Ersan, M. (2006). Türkiye Selçuklularında devlet erkanının eğlence hayatı. Tarih Incelemeleri Dergisi, 21(1): 73-106.
30. Erzi, A.S. (1956). İbnBîbî, el-Evâmirü'lAlâiyyefî'l-Umûri'l-Alâiyye. Ankara: Tıpkı Basım.

31. Eflakî. (1980). Menâkib al-Ârifin. (I-II, Yay. Tahsin Yazıcı), Ankara: TTK.

32. Merçil, E. T. (2000). Selçukluları'nda meslekler. Ankara: TTK.

33. Uzunçarş11, İ.H. (1988). Osmanlı Devleti teşkilâtına medhal. Ankara: TTK.

34. Göksu, E. (2010). Ok ve yayın Türk devlet geleneği ve hâkimiyet anlayışındaki yeri. Turkish Studies, 5(2), 986-1011.

35. Turan, O. (1969). Selçuklular tarihi ve Türk-İslam medeniyeti (Vol. 6). Ötüken Neşriyat AŞ.

36. Sarmış, İ. (1983). Suph es-Salih, İslam Mehzepleri ve Müesseseleri. İstanbul.

37. Turan, O. (1996). Selçuklular zamanında Türkiye. İstanbul: Boğaziçi Yayınları.

38. Sümer, F. (1992). Çepniler - Anadolu'da Türk yerleşmesinde önemli rol oynayan bir Oğuz Boyu, İstanbul; 1992.

39. Kalyoncuoğlu, S. (2010). Selçuklularda iç güvenlik. Yüksek Lisans Tezi. Afyon Üniversitesi, Sosyal Bilimler Enstitüsü, Tarih Anabilim Dalı.

40. Köymen, M.A. (1979). Büyük Selçuklu İmparatorluğu Tarihi I (Kuruluş Devri). Ankara, 1979

41. Fayol, H. (1999). Administration industrielle et générale. Paris: H.Dunod ET E.Pinat Editeurs.

42. Peaucelle, J.L. (2003). L'outilla gead ministratif, J.L. Peaucelle (der.), Henri Fayol, İnventeurdes Outils de Gestion içinde, Paris: Economica. 